IRA-International Journal of Applied Sciences ISSN 2455-4499; Vol.08, Issue 03 (September 2017)

Pg. no. $73-82$

Institute of Research Advances

https://research-advances.org/index.php/IRAJAS

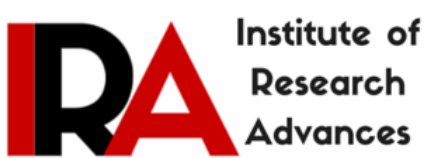

\title{
Chemical Composition of Some Natural Palm Wine Preservatives
}

\author{
Ngounou Batchanji Steve ${ }^{1}$, Feumba Dibanda Romelle ${ }^{2}$, Yadang Germaine ${ }^{2}$, Nyobe \\ Emillienne Carine $^{2}$, Achegui Nestor ${ }^{2}$, Ndanga Thomas ${ }^{2}$, Medoua Nama Gabriel ${ }^{2}$ \\ ${ }^{1}$ Department of Biochemistry, Faculty of Sciences, University of Yaounde I, Cameroon. \\ ${ }^{2}$ Food and Nutrition Research Centre, Institute of Medical Research and Medicinal Plants Studies, Cameroon.
}

Type of Review: Peer Reviewed.

DOI: http://dx.doi.org/10.21013/jas.v08.n03.p01

How to cite this paper:
Steve, N.B., Romelle, F.D., Germaine, Y., Carine, N.E., Nestor, A., Thomas, N., Gabriel, M.N. (2017).
Chemical Composition of Some Natural Palm Wine Preservatives. IRA International Journal of Applied
Sciences (ISSN 2455-4499), 8(3), 73-82. doi:http://dx.doi.org/10.21013/jas.v08.n03.p01

(C) Institute of Research Advances.

\section{(cc) $\mathrm{EY}$-NO}

This work is licensed under a Creative Commons Attribution-Non Commercial 4.0International License subject to proper citation to the publication source of the work.

Disclaimer: The scholarly papers as reviewed and published by the Institute of Research Advances (IRA) are the views and opinions of their respective authors and are not the views or opinions of the IRA. The IRA disclaims of any harm or loss caused due to the published content to any party.

Institute of Research Advances is an institutional publisher member of Publishers Inter Linking Association Inc. (PILA-CrossRef), USA. The institute is an institutional signatory to the Budapest Open Access Initiative, Hungary advocating the open access of scientific and scholarly knowledge. The Institute is a registered content provider under Open Access Initiative Protocol for Metadata Harvesting (OAI-PMH).

The journal is indexed \& included in CAS Source Index of Chemical Abstracts Service of American Chemical Society (USA), WorldCat Discovery Service (USA), CrossRef Metadata Search (USA), WorldCat (USA), OCLC (USA), Open J-Gate (India), EZB (Germany) Scilit (Switzerland), Airiti (China), Bielefeld Academic Search Engine (BASE) of Bielefeld University, Germany, PKP Index of Simon Fraser University, Canada. 


\begin{abstract}
Palm wine is the commonest name of the beverage obtained from fermented palm sap, the exudate from tapped unopened spathe of oil palm tree (Elaeis guineensis). This refreshing wine of West and Central Africa is very sweet but within 24 hours the concentration of sucrose falls to less than 50\% the initial amounts due to a rapid sugar fermentation by microorganisms. In Cameroon, Central Africa, traditional attempts to preserve palm wine imply the introduction of natural preservatives mostly barks and leaves from edible or medicinal plants. The leaves of Cymbopogon citratus, Pimenta racemosa, Vernonia amygdalina, Ocimum basilicum and the barks and the leaves of Garcinia lucida and of Adansonia digitata commonly used in palm wine preservation were analyzed for their chemical composition. The results showed that lipid, protein, ash, crude fiber, total sugars and vitamin $C$ contents were respectively from $15.70 \pm 1.13$ to $23.57 \pm 1.80 \%$, from $8.38 \pm$ 0.38 to $43.81 \pm 3.69 \%$, from $1.14 \pm 0.17$ to $10.06 \pm 0.39 \%$, from $11.74 \pm 1.11$ to $48.42 \pm$ $0.55 \%$, and from $1.49 \pm 0.02$ to $22.56 \pm 0.59 \%$ and from $55.76 \pm 3.15$ to $175.71 \pm 2.09 \mu \mathrm{g}$ $1100 \mathrm{~g} \mathrm{dw}$. The phyto-chemicals levels were respectively from $1.37 \pm 0.22$ to $3.61 \pm 0.6 \%$ for total alkaloids, $2.66 \pm 0.12$ to $4.80 \pm 0.24 \%$ for total phenolics and $0.57 \pm 0.09$ to $1.88 \pm$ $0.09 \mathrm{mg} / 100 \mathrm{~g} \mathrm{dw}$ for total saponins. Concerning anti-nutrients, the oxalates levels were higher than the threshold value $(250 \mathrm{mg} / 100 \mathrm{~g})$ reported as safety limit. Despise the proven antimicrobial benefits of alkaloids, saponins and phenolics found in those leaves and barks, caution shall be paid during their use due to their high oxalates levels.
\end{abstract}

KEYWORDS: Palm wine, Natural preservatives, Cymbopogon citratus, Pimenta racemosa, Vernonia amygdalina, Ocimum basilicum, Garcinia lucida, Adansonia digitata, oxalates.

\title{
INTRODUCTION
}

The unfermented exudate from tapped unopened spathe of oil palm tree (Elaeis guineensis) is referred to as palm sap. It is widely consumed as a refreshing beverage in West and Central Africa [1]. The fermented palm sap, called palm wine is the commonest form of the beverage. Before, the consumption of the beverage (palm sap/wine) was a common feature in virtually all ceremonies (traditional festivals, weddings and funerals) where it was served as an indication of hospitality [2]. Nowadays, the drink is becoming more and more present in the diet as it is supplied daily in restaurant or sold in the street.

Fresh palm wine is very sweet and refreshing because of the presence of sucrose, but within 24 hours the concentration of sucrose falls to less than $50 \%$ the initial amounts due to a rapid sugar fermentation by microorganisms. Fermentation virtually ends when the $\mathrm{pH}$ falls to 4.0; the whole process lasts about 48 hours resulting in an undesirable sour drink. Microorganisms reported in palm wine include Bacillus, Streptococcus, Saccharomyces, Schizosaccharomyces, Pischia, Leuconostoc, Micrococcus, Serratia, Aerobacter, Pseudomonas, Cornybacterium, Asppergillus, and Candida [1].

In Cameroon, traditional attempts to preserve palm wine imply the introduction of natural preservatives mostly barks and leaves from edible or medicinal plants like Vernonia amygdalina, Cymbopogon citratus, etc. So, palm wine is supplied and drank with those preservatives inside. Due to their chemical composition, these preservatives offer chemical compounds (essential oils, alkaloids, phenolic compounds, etc.) preventing the microbial activity $[3,4]$ and therefore increasing the shelf life of palm wine.

Besides bioactive compounds, those preservatives also provide nutrients and antinutrients influencing therefore the nutritional quality of palm wine. However, to our knowledge, little information is available on the chemical composition of those barks and leaves. This study aims to assess the nutritional composition of some barks and leaves used in palm wine preservation as well as their bioactive compounds. 


\section{MATERIALS AND METHODS}

\section{Procurement of leaves and barks}

The samples used for the experiment were the leaves of Cymbopogon citratus (Citronella), Pimenta racemosa (bay leaf), Vernonia amygdalina (bitter leaf), Ocimum basilicum (Massep); the barks and the leaves of Garcinia lucida (Essok) and of Adansonia digitata (baobab). The samples were purchased at Mfoundi market and in a farm at Nkolbisson (Yaounde, Cameroon). Leafy stem specimen collected from the samples were identified at the Cameroonian National Herbarium.

\section{Preparation of samples}

Fresh leaves and barks were selected, washed and dried at $50{ }^{\circ} \mathrm{C}$. Then, the samples were grinded and sieved to obtain a fine powder whose particle size was $500 \mu \mathrm{m}$.

\section{Evaluation of nutritional composition}

\section{Evaluation of proximate composition}

Moisture content was determined after oven drying to a constant weight at $105{ }^{\circ} \mathrm{C}$. Ash, proteins, lipids and crude fibers were analyzed according to AOAC methods [5,6].

\section{Determination of ascorbic acid level}

An amount of $0.5 \mathrm{~g}$ was stirred twice during $15 \mathrm{~min}$ in presence of $10 \mathrm{~mL} 90 \%$ acetic acid, then filtrated into 20 $\mathrm{mL}$ standard flask and the volume was adjusted to the mark with $90 \%$ acetic acid. About $0.5 \mathrm{~mL}$ of filtrate was mixed with $4.5 \mathrm{~mL}$ of $50 \mu \mathrm{mol} / \mathrm{L} 2.6$ dichloroindophenol sodium salt hydrate and the absorbance was measured within $30 \mathrm{~min}$ at $515 \mathrm{~nm}$. Ascorbic acid content was calculated on the basis of the calibration curve of Lascorbic acid ranging from 0.2 to $0.4 \mu \mathrm{g} / \mathrm{mL}$ [7].

\section{Determination of antinutrients}

\section{Determination of oxalates content}

A specimen $(2 \mathrm{~g})$ was digested with $10 \mathrm{~mL}$ of $6 \mathrm{M}$ hydrogen chloride and $190 \mathrm{~mL}$ of distilled water. The filtrate was put in a conical flask of $250 \mathrm{~mL}$ with distilled water. The $\mathrm{pH}$ of the solution was increased using liquid ammonia until the color moved from salmon pink to fair yellow then, the filtrate was treated with $10 \mathrm{~mL}$ of $5 \%$ chloride of calcium for oxalate precipitation. Afterwards, the mixture which was allowed to settle for $24 \mathrm{~h}$ was centrifuged and the precipitate dissolved in $10 \mathrm{~mL}$ of $20 \%$ sulphuric acid. The total filtrate resulting from the dissolution in $20 \%$ sulphuric acid was completed to $300 \mathrm{~mL}$ with distilled water. An aliquot of $125 \mathrm{~mL}$ was heated until boiling and titrated with potassium permanganate $0.098 \mathrm{~N}$ until a constant pink during $30 \mathrm{~s}$ [8].

\section{Determination of hydrogen cyanide content}

Hydrogen cyanide content was determined as described by [9]. Sample (1 g) was soaked in a mixture of $200 \mathrm{~mL}$ of water and $10 \mathrm{~mL}$ of orthophosphoric acid. The mixture was left $12 \mathrm{~h}$ to release all bounded hydrocyanic acid. Antibumping agents were added, the solution distilled and the distillate measured. A volume of $10 \mathrm{~mL}$ of distillate was taken into a conical flask and diluted with $20 \mathrm{~mL}$ of water, $4 \mathrm{~mL}$ of $6 \mathrm{M}$ ammonia and $1 \mathrm{~mL} 5 \%$ potassium iodide. The mixture was titrated with $0.02 \mathrm{M}$ silver nitrate until a faint but permanent turbidity was 


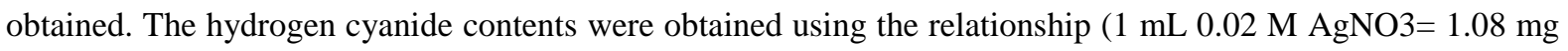
$\mathrm{HCN}$ ).

\section{Determination of phytates content}

An amount of $150 \mathrm{mg}$ of sample was extracted with $5 \mathrm{~mL}$ of $2.4 \%$ hydrochloric acid during $2 \mathrm{~h}$. A volume of $50 \mu \mathrm{L}$ of extract was added to $750 \mu \mathrm{L}$ of Wade solution $(0.15 \mathrm{~g}$ of sulfosalicylic acid and $15 \mathrm{mf}$ of ferric chloride in $50 \mathrm{~mL}$ of water) and the absorbance was read at $500 \mathrm{~nm}$. The calibration curve of phytic acid ranged from 70 to $300 \mu \mathrm{g} / \mathrm{mL}[10]$.

\section{Estimation of phytochemicals}

\section{Determination of alkaloids content}

A total of $20 \mathrm{~mL}$ of $20 \%$ acetic acid was added to $0.5 \mathrm{~g}$ of sample taken in a separate $250 \mathrm{~mL}$ beaker and covered to stand for $4 \mathrm{~h}$. This mixture containing solution was filtered and the volume was reduced to one quarter using water bath. To this sample, concentrated ammonium hydroxyde was added drop-wise until the precipitate was complete. The whole solution was allowed to settle and the precipitate was collected by filtration and weighed [11].

\section{Estimation of total saponins content}

Estimation of total saponins content was determined by the method described by [12]. A mass of $0.5 \mathrm{~g}$ of sample was extracted twice with $25 \mathrm{~mL}$ of ethanol $80 \%$ for $30 \mathrm{~min}$. About $50 \mu \mathrm{L}$ of extract was added with $250 \mu \mathrm{L}$ of distilled water. To this, about $250 \mu \mathrm{L}$ of vanillin reagent $(800 \mathrm{mg}$ of vanillin in $10 \mathrm{~mL}$ of $99.5 \%$ ethanol) was added. Then $2 \mathrm{~mL}$ of $72 \%$ sulphuric acid was added and it was mixed well. This solution was kept in a water bath at $60{ }^{\circ} \mathrm{C}$ for $10 \mathrm{~min}$. After $10 \mathrm{~min}$, it was cooled in ice cold water and the absorbance was read at $544 \mathrm{~nm}$. The values were expressed as mg saponin equivalent (mg SE / of 100g) derived from a standard curve.

\section{Determination of total phenolics content}

About $0.5 \mathrm{~g}$ of sample was introduced into a round bottom flask and extracted twice with $25 \mathrm{~mL}$ of ethanol 80 $\%$ on a magnetic stirrer for $30 \mathrm{~min}$. After this, the mixtures were filtered with a Wathman filter paper $\mathrm{N}^{\circ} 1$ and the filtrates were poured in $50 \mathrm{~mL}$ standard flasks and the volume were adjusted to the mark using ethanol $80 \%$. To $125 \mu \mathrm{L}$ of extract, were added $0.5 \mathrm{~mL}$ of distilled water and $125 \mu \mathrm{L}$ of the Folin Ciocalteau solution (1:16). After $6 \mathrm{~min}, 1250 \mu \mathrm{L}$ of $7 \%$ sodium carbonate were added and the volume was adjusted to $3 \mathrm{~mL}$ with distilled water and the absorbance measured after 90 min against a blank tube containing extracting solvent at $760 \mathrm{~nm}$. The calibration curve of gallic acid ranged from 1 to $5 \mu \mathrm{g} / \mathrm{mL}$ [13].

\section{RESULTS AND DISCUSSION}

\section{Evaluation of nutritional composition}

The nutritional composition of palm wine preservatives was presented in table 1 . As displayed in table 1, in the eight leaves and barks used for palm wine preservation, the lipids content ranged from $15.70 \pm 1.13$ to $23.57 \pm$ $1.80 \mathrm{~g} / 100 \mathrm{~g} \mathrm{dw}$; the minimum level was found in Vernonia amygdalina leaves and the maximum in Garcinia lucida leaves. This lipids content found in Vernonia amydalina leaves $(15.70 \pm 1.13 \mathrm{~g} / 100 \mathrm{~g} \mathrm{dw})$ was higher than 11.3 and $6.04 \%$ reported respectively by $[4,14]$ to be the lipids content of Vernonia amydalina leaves. 
The ash content of leaves and barks under study varied from $1.14 \pm 0.17 \mathrm{~g} / 100 \mathrm{~g} \mathrm{dw}$ in Garcinia lucida bark to $10.06 \pm 0.39 \mathrm{~g} / 100 \mathrm{~g} \mathrm{dw}$ in Vernonia amygdalina leaves. The concentrations of ash found in Vernonia amygdalina leaves $(10.60 \pm 0.39 \mathrm{~g} / 100 \mathrm{~g} \mathrm{dw})$ and in Cymbopogon citratus leaves $(7.87 \pm 0.10 \mathrm{~g} / 100 \mathrm{~g} \mathrm{dw})$ were consistent with the levels found respectively in Vernonia amygdalina (11.8\%) by [4] and in Cymbopogon citratus $(7.15 \pm 0.21 \%)$ by $[15]$.

Table 1. Nutritional composition of some palm wine preservatives

\begin{tabular}{|c|c|c|c|c|c|c|c|}
\hline Plants & Part & $\begin{array}{l}\text { Lipids } \\
(\mathrm{g} / 100 \mathrm{~g} \\
\mathrm{dw})\end{array}$ & $\begin{array}{l}\text { Ash } \\
(\mathrm{g} / 100 \mathrm{~g} \\
\mathrm{dw})\end{array}$ & $\begin{array}{l}\text { Total } \\
\text { sugar } \\
(\mathrm{g} / 100 \mathrm{~g} \\
\text { dw) }\end{array}$ & $\begin{array}{l}\text { Crude } \\
\text { fibers } \\
\text { (g/100 g } \\
\text { dw) }\end{array}$ & $\begin{array}{l}\text { Crude } \\
\text { proteins } \\
(\mathrm{g} / 100 \mathrm{~g} \\
\mathrm{dw})\end{array}$ & $\begin{array}{l}\text { Ascorbic } \\
\quad \text { acid } \\
(\mu \mathrm{g} / 100 \mathrm{~g} \\
\mathrm{dw})\end{array}$ \\
\hline $\begin{array}{l}\text { Vernonia } \\
\text { amygdalina }\end{array}$ & Leaf & $\begin{array}{l}15.70 \pm \\
1.13^{\mathrm{a}}\end{array}$ & $\begin{array}{l}10.60 \pm \\
0.39^{\mathrm{a}}\end{array}$ & $\begin{array}{l}3.08 \pm \\
0.01^{\mathrm{a}}\end{array}$ & $\begin{array}{l}16.97 \pm \\
1.11^{\mathrm{a}}\end{array}$ & $\begin{array}{l}43.81 \pm \\
3.69^{\mathrm{a}}\end{array}$ & $\begin{array}{l}118.36 \pm \\
8.37^{\mathrm{a}}\end{array}$ \\
\hline $\begin{array}{l}\text { Cymbopogon } \\
\text { citratus }\end{array}$ & Leaf & $\begin{array}{l}19.94 \pm \\
0.10^{\mathrm{b}}\end{array}$ & $\begin{array}{l}7.87 \pm \\
0.10^{\mathrm{b}}\end{array}$ & $\begin{array}{l}22.56 \pm \\
0.59^{\mathrm{b}}\end{array}$ & $\begin{array}{l}38.12 \pm \\
0.36^{\mathrm{b}}\end{array}$ & $\begin{array}{l}14.06 \pm \\
0.88^{\mathrm{b}}\end{array}$ & $\begin{array}{l}104.05 \pm \\
2.13^{\mathrm{b}}\end{array}$ \\
\hline $\begin{array}{l}\text { Pimenta } \\
\text { racemosa }\end{array}$ & Leaf & $\begin{array}{l}18.82 \pm \\
0.91^{\mathrm{c}}\end{array}$ & $\begin{array}{l}3.30 \pm \\
0.07^{\mathrm{c}}\end{array}$ & $\begin{array}{l}1.69 \pm \\
0.18^{\mathrm{c}}\end{array}$ & $\begin{array}{l}38.91 \pm \\
0.55^{\mathrm{b}}\end{array}$ & $\begin{array}{l}14.00 \pm \\
1.56^{\mathrm{b}}\end{array}$ & $\begin{array}{l}153.81 \pm \\
4.27^{\mathrm{c}}\end{array}$ \\
\hline $\begin{array}{l}\text { Ocimum } \\
\text { basilicum }\end{array}$ & Leaf & $\begin{array}{l}19.05 \pm \\
0.12^{\mathrm{c}}\end{array}$ & $\begin{array}{l}10.05 \pm \\
1.10^{\mathrm{a}}\end{array}$ & $\begin{array}{l}2.97 \pm \\
0.18^{\mathrm{a}}\end{array}$ & $\begin{array}{l}11.74 \pm \\
1.11^{\mathrm{c}}\end{array}$ & $\begin{array}{l}29.94 \pm \\
2.31^{\mathrm{c}}\end{array}$ & $\begin{array}{l}87.71 \pm \\
12.83^{\mathrm{d}}\end{array}$ \\
\hline $\begin{array}{l}\text { Adansonia } \\
\text { digitata }\end{array}$ & Bark & $\begin{array}{l}17.44 \pm \\
0.71^{\mathrm{d}}\end{array}$ & $\begin{array}{l}7.90 \pm \\
1.90^{\mathrm{bd}}\end{array}$ & $\begin{array}{l}1.89 \pm \\
0.08^{\mathrm{c}}\end{array}$ & $\begin{array}{l}42.84 \pm \\
1.75^{\mathrm{d}}\end{array}$ & $\begin{array}{l}7.88 \pm \\
0.50^{\mathrm{d}}\end{array}$ & $\begin{array}{l}92.61 \pm \\
4.22^{\mathrm{e}}\end{array}$ \\
\hline $\begin{array}{l}\text { Adansonia } \\
\text { digitate }\end{array}$ & Leaf & $\begin{array}{l}22.17 \pm \\
2.72^{\text {bd }}\end{array}$ & $\begin{array}{l}5.52 \pm \\
1.05^{\mathrm{d}}\end{array}$ & $\begin{array}{l}1.49 \pm \\
0.02^{\mathrm{c}}\end{array}$ & $\begin{array}{l}48.42 \pm \\
0.55 \mathrm{e}\end{array}$ & $\begin{array}{l}21.88 \pm \\
0.95^{\mathrm{e}}\end{array}$ & $\begin{array}{l}55.76 \pm \\
3.15^{\mathrm{f}}\end{array}$ \\
\hline $\begin{array}{l}\text { Garcinia } \\
\text { lucida }\end{array}$ & Bark & $\begin{array}{l}16.28 \pm \\
0.20^{\mathrm{a}}\end{array}$ & $\begin{array}{l}1.14 \pm \\
0.17^{\mathrm{e}}\end{array}$ & $\begin{array}{l}2.12 \pm \\
0.07^{\mathrm{d}}\end{array}$ & $\begin{array}{l}20.37 \pm \\
0.35^{\mathrm{f}}\end{array}$ & $\begin{array}{l}10.00 \pm \\
0.13^{\mathrm{f}}\end{array}$ & $\begin{array}{l}83.41 \pm \\
8.43^{\mathrm{e}}\end{array}$ \\
\hline $\begin{array}{l}\text { Garcinia } \\
\text { lucida }\end{array}$ & Leaf & $\begin{array}{l}23.57 \pm \\
1.80^{\mathrm{d}}\end{array}$ & $\begin{array}{l}4.22 \pm \\
0.69^{\mathrm{f}}\end{array}$ & $\begin{array}{l}3.46 \pm \\
0.11^{\mathrm{e}}\end{array}$ & $\begin{array}{l}20.37 \pm \\
0.35^{\mathrm{f}}\end{array}$ & $\begin{array}{l}8.38 \pm \\
0.38^{\mathrm{d}}\end{array}$ & $\begin{array}{l}175.71 \pm \\
2.09^{\mathrm{g}}\end{array}$ \\
\hline
\end{tabular}

Means values within a column having differing superscripts are significantly different at $\mathrm{P}<0.05$

Concerning the crude fibers content of leaves and barks analyzed, the values ranged from $11.74 \pm 1.11$ to 48.42 $\pm 0.55 \mathrm{~g} / 100 \mathrm{~g} \mathrm{dw}$. The crude fibres level observed in Cymbopogon citratus $(38.12 \pm 0.36 \mathrm{~g} / 100 \mathrm{~g} \mathrm{dw}) \mathrm{was}$ similar to the content obtained in leaves of Cymbopogon citratus $(37.53 \pm 0.67 \%)$ by [15] but lower than 55\% obtained by [16]. The fiber content obtained for Vernonia amygdalina leaves $(16.97 \pm 1.11 \%)$ is lower than $25.47 \%$ reported by [17]. 
The total sugars and ascorbic acid contents of these eight leaves and barks respectively ranged from $1.49 \pm 0.02$ to $22.56 \pm 0.59 \mathrm{~g} / 100 \mathrm{~g} \mathrm{dw}$ and from $55.76 \pm 3.15$ to $175.71 \pm 2.09 \mu \mathrm{g} / 100 \mathrm{~g} \mathrm{dw}$. The ascorbic acid content of the Vernonia amygdalina leaves $(118.36 \pm 8.37 \mu \mathrm{g} / 100 \mathrm{~g} \mathrm{dw})$ was higher than the value $(52.0 \mathrm{mg} / 100 \mathrm{~g})$ reported by [18] for Vernonia amygdalina.

The protein content of leaves and barks under study varied from $8.38 \pm 0.38$ to $43.81 \pm 3.69 \%$. The protein level observed in Cymbopogon citratusleaves (14.06 $\pm 0.88 \mathrm{~g} / 100 \mathrm{~g} \mathrm{dw})$ was similar to $15.68 \pm 0.83 \%$ reported by [19] about Cymbopogon citratus leaves. The protein content found in Vernonia amygdalina leaves $(43.81 \pm 3.69 \%)$ was higher than $34.56 \%$ reported by[14].

The variations observed in the results may be due to the difference in the geographical conditions (location, soil, climate) where the plants were grown and to their strains [20].

\section{Assessment of phytochemicals}

The presence of secondary metabolites (alkaloids, saponins, etc.) in the palm wine preservatives may contribute to its biological value. The bioactive components of the different palm wine preservatives under study were presented in table 2 .

Table 2. Phytochemicals of some palm wine preservatives

\begin{tabular}{|c|c|c|c|c|}
\hline $\begin{array}{l}\text { Palm wine } \\
\text { Preservatives }\end{array}$ & Part & $\begin{array}{c}\text { Alkaloids } \\
(\mathrm{g} / 100 \mathrm{~g} \mathrm{dw})\end{array}$ & $\begin{array}{l}\text { Total phenolics } \\
(\mathrm{g} / 100 \mathrm{~g} \mathrm{dw})\end{array}$ & $\begin{array}{l}\text { Total saponins } \\
(\mathrm{mg} / 100 \mathrm{~g} \mathrm{dw})\end{array}$ \\
\hline $\begin{array}{l}\text { Vernonia } \\
\text { amygdalina }\end{array}$ & Leaf & $2.59 \pm 0.41^{\mathrm{a}}$ & $4.24 \pm 0.14^{\mathrm{a}}$ & $0.57 \pm 0.09^{\mathrm{ac}}$ \\
\hline $\begin{array}{l}\text { Cymbopogon } \\
\text { citratus }\end{array}$ & Leaf & $1.37 \pm 0.22^{b}$ & $3.91 \pm 0.14^{b}$ & $0.59 \pm 0.01^{\mathrm{a}}$ \\
\hline Pimenta racemosa & Leaf & $1.59 \pm 0.83^{b}$ & $4.80 \pm 0.24^{\mathrm{c}}$ & $1.03 \pm 0.03^{b}$ \\
\hline Ocimum basilicum & Leaf & $3.61 \pm 0.60^{\mathrm{c}}$ & $2.66 \pm 0.12^{\mathrm{d}}$ & $0.67 \pm 0.04^{\mathrm{c}}$ \\
\hline $\begin{array}{l}\text { Adansonia } \\
\text { digitata }\end{array}$ & Bark & $2.05 \pm 0.90^{\mathrm{d}}$ & $4.24 \pm 0.31 b^{\mathrm{e}}$ & $1.56 \pm 0.06^{\mathrm{d}}$ \\
\hline $\begin{array}{l}\text { Adansonia } \\
\text { digitata }\end{array}$ & Leaf & $2.64 \pm 0.57^{\mathrm{abcd}}$ & $3.03 \pm 0.26^{\mathrm{d}}$ & $0.59 \pm 0.05^{\mathrm{ac}}$ \\
\hline Garcinia lucida & Bark & $2.55 \pm 0.88^{\mathrm{abcd}}$ & $4.70 \pm 0.15^{\mathrm{ce}}$ & $1.41 \pm 0.01^{\mathrm{e}}$ \\
\hline Garcinia lucida & Leaf & $3.15 \pm 0.23^{\mathrm{ad}}$ & $4.12 \pm 0.55^{c}$ & $1.32 \pm 0.04^{f}$ \\
\hline
\end{tabular}

Means values within a column having differing superscripts are significantly different at $\mathrm{P}<0.05$ 
The presence of secondary metabolites (alkaloids, saponins, etc.) in the preservatives added to palm wine may contribute to its biological value. The alkaloids content in wine preservatives ranged from $1.37 \pm 0.22$ to $3.61 \pm$ $0.6 \%$, Ocimum basilicum having the highest alkaloids content and Cymbopogon citratus the lowest. Alkaloids are known to be the most essential potent anti-inflammatory agents of naturally occurring products of secondary metabolism [21].

The phenolics content of leaves and barks varied from $2.66 \pm 0.12$ to $4.80 \pm 0.24 \%$. Ocimum basilicum and Pimenta racemosa contained respectively the lowest and the highest phenolics content. Phenolic compounds have been reported to exhibit a wide range of biological effects including anti-bacterial, anti-inflammatory and antioxidant properties [22].

The saponins content of leaves and barks under study varied from $0.57 \pm 0.09 \mathrm{mg} / 100 \mathrm{~g} \mathrm{dw}$ in Vernonia amygdalina to $1.88 \pm 0.09 \mathrm{mg} / 100 \mathrm{~g} \mathrm{dw}$ in Garcinia lucida barks. Saponins have been found useful in the formulation of drugs, in food, drinks and beverage industries as foaming agents [23]. In addition, saponins and phenolic compounds have been reported to have antibiotic, antifungal and antiviral activities [24].

\section{Estimation of antinutrients levels}

Anti-nutrient factors are compounds which act to reduce nutrients utilization [25]. The antinutrients of the different palm wine preservatives analyzed were presented in table 3.

Table 3. Antinutrients levels of some palm wine preservatives

\begin{tabular}{|l|l|l|c|c|}
\hline Palm wine Preservatives & Part & \multicolumn{1}{|c|}{ Phytates } & Oxalates & Hydrogen cyanide \\
$(\mathrm{g} / 100 \mathrm{~g} \mathrm{dw})$ & $(\mathrm{g} / 100 \mathrm{~g} \mathrm{dw})$ & $(\mu \mathrm{g} / 100 \mathrm{~g} \mathrm{dw})$ \\
\hline Vernonia amygdalina & Leaf & $1.52 \pm 0.14^{\mathrm{a}}$ & $6.48 \pm 1.15^{\mathrm{a}}$ & $118.36 \pm 8.37^{\mathrm{a}}$ \\
\hline Cymbopogon citratus & Leaf & $5.57 \pm 0.28^{\mathrm{b}}$ & $1.24 \pm 0.58^{\mathrm{b}}$ & $104.05 \pm 2.13^{\mathrm{b}}$ \\
\hline Pimenta racemosa & Leaf & $1.18 \pm 0.56^{\mathrm{ad}}$ & $1.68 \pm 0.01^{\mathrm{b}}$ & $153.81 \pm 4.26^{\mathrm{c}}$ \\
\hline Ocimum basilicum & Leaf & $4.03 \pm 1.71^{\mathrm{be}}$ & $2.10 \pm 0.59^{\mathrm{b}}$ & $87.71 \pm 12.83^{\mathrm{d}}$ \\
\hline Adansonia digitata & Bark & $9.76 \pm 2.18^{\mathrm{c}}$ & $11.08 \pm 0.58^{\mathrm{c}}$ & $92.61 \pm 4.22^{\mathrm{d}}$ \\
\hline Adansonia digitata & Leaf & $0.71 \pm 0.14^{\mathrm{d}}$ & $1.72 \pm 0.01^{\mathrm{b}}$ & $55.76 \pm 3.15^{\mathrm{e}}$ \\
\hline Garcinia lucida & Bark & $2.79 \pm 0.28^{\mathrm{e}}$ & $5.72 \pm 1.15^{\mathrm{a}}$ & $83.41 \pm 8.43^{\mathrm{d}}$ \\
\hline Garcinia lucida & Leaf & $3.22 \pm 0.01^{\mathrm{f}}$ & $12.06 \pm 0.01^{\mathrm{d}}$ & $175.72 \pm 2.09^{\mathrm{e}}$ \\
\hline
\end{tabular}

Means values within a column having differing superscripts are significantly different at $\mathrm{P}<0.05$

Phytic acid in plants is known for its chelating effect on certain essential mineral elements such as $\mathrm{Ca}, \mathrm{Mg}, \mathrm{Fe}$ and $\mathrm{Zn}$ to form insoluble phytate salts [26]. Phytates in leaves and barks analyzed ranged from $0.71 \pm 0.14$ to 
$9.76 \pm 2.18 \%$. The lowest level was found in Adansonia digitata leaves and the highest in Adansonia digitata barks. The phytates content of Vernonia amygdalina leaves is quite higher than $1.31 \pm 0.03 \%$ observed by [14]. Oxalates can bind to calcium in food thereby rendering calcium unavailable for normal physiological and biochemical roles [27]. The oxalate content in the eight leaves and barks under study ranged from $1.24 \pm 0.58$ to $12.6 \pm 0.01 \%$. The lowest content was found in Cymbopogon citratus leaves and the highest in its barks. The oxalates levels observed in Vernonia amygdalina leaves is higher than $0.96 \%$ reported by [14]. In the palm wine preservatives under study, the oxalates contents are higher than the permissible level which is of 250 $\mathrm{mg} / 100 \mathrm{~g}$ fresh sample[28].

Hydrogen cyanide is an extremely poisonous substance formed by the action of acids on metal cyanides. The levels of hydrogen cyanides ranged from $55.76 \pm 3.15$ to $175.72 \pm 2.09 \mu \mathrm{g} / 100 \mathrm{~g} \mathrm{dw}$. The lowest level was obtained in Adansonia digitata leaves and the highest in Garcnia lucida leaves. Large dose of hydrogen cyanide can cause death within few minutes, while smaller dosages may result to stiffness of the throat, chest, palpitation and muscle weakness. The result obtained falls within the threshold value (below $350 \mathrm{mg} / 100 \mathrm{~g}$ ) reported as safety limit [29].

\section{CONCLUSION}

The leaves of Cymbopogon citratus (Citronella), Pimenta racemosa (bay leaf), Vernonia amygdalina (bitter leaf), Ocimum basilicum (Massep); the barks and the leaves of Garcinia lucida (Essok) and of Adansonia digitata (baobab) used in palm wine preservation contain nutrients (lipids, proteins, minerals, etc.) and phytochemicals (alkaloids, saponins, phenolics). However, their levels of some anti-nutrients (oxalates) are above the safety limits. Therefore, caution should be paid when using those leaves and barks in palm wine preservation.

\section{REFERENCES}

[1] Ezeagu I. E. and Fafunso M. A. (2003). Biochemical constituents of palm wine. Ecology of Food and Nutrition, 42,255-264.

[2] Ikegwu M. T., Okafor G. I. and Ochiogu I. S. (2015). Effect of preservation methods of oil palm (Elaeis guineensis) sap on health status of male Wistar rats. American Journal of Food Science and Technology, 3(5),137-144.

[3] Adebayo O. L., Abugri J., Sumabe B. K. and Onilimor P. J. (2014). Leaf extracts of Vernonia amygdalina Del. from northern Ghana contain bioactive agents that inhibit the growth of some betalactamase producing bacteria in vitro. British Journal of Pharmaceutical Research, 4(2),192-202.

[4] Udochukwu U., Omeje F. I., Uloma I. S. and Oseiw F. D. (2015). Phytochemical analysis of Vernonia amygdalina and Ocimum gratissimum extracts and their antibacterial activity on some drug resistant bacteria. American Journal of Research Communication, 3(5),225-235.

[5] AOAC (1990). Official methods of analysis (14th ed.). Association of Official Analytical Chemists, Washington, D.C.,USA.

[6] AOAC (2000). Official methods of analysis (17th ed.). Association of Official Analytical Chemists, Arlington, VA.,USA. 
[7] Klein B. P. and Perry A. K. (1982). Ascorbic acid and vitamin A activity in selected vegetables from different geographical areas of the United States. Journal of Food Science, 47,941-945.

[8] Oke O. L. (1966). Chemical studies on some Nigerian vegetables. Tropical Science. 8(3),128-132.

[9] AOAC (1995). Official methods of analysis (16th ed.). Association of Official Analytical Chemists, Arlington, VA.,USA.

[10] Gao Y., Shang C., Maroof M. A. S., Biyashev R. M., Grabau E. A., Kwanyuen P., Burton J. W. and Buss G. R. (2007). A modified colorimetric method for phytic acid analysis in soybean. Crop Science, 47,1797-1803.

[11] Jamuna S., Paulsamy S. and Karthika K. (2014). Phytochemical analysis and evaluation of leaf and roots parts of the medicinal herb, Hypochaeris radicata L. for in vitro antioxidant activities. Asian Pacific Journal of Tropical Biomedicine,S359-S367.

[12] Makkar H. P., Siddhuraju P. and Becker K. (2007). Methods in molecular biology: plant secondary metabolites. Totowa: Human Press,93-100.

[13] Dewantoo V., Wu X., Adam K. K. and Liu R. H. (2002). Thermal processing enhances the nutritional value of tomatoes by increasing total antioxidant activity. Journal of Agricultural and Food chemistry, 50,3010-3014.

[14] Shokunbi O. S., Ogochukwu A. A., Oluwatosin S. S. and Oluwatoyin T. G. (2011). Effect of postharvest processing on the nutrient and anti-nutrient compositions of Vernonia amygdalina leaf. African Journal of Biotechnology, 10(53),10980-10985.

[15] AnayoJ.U.,ChukwudozieS.O.,NzubeE.,NkiruE.,EjiM.Ogbanshi,ChukwuE.,UchechukwuB.

N. and Chukwuemeka M. O. (2015). Nutritional and Antinutritional quantification Assessment of Cymbopogon citratus leaf. Pharmacology \& Pharmacy, 6, 401-410.

[16] Asaolu M. F., Oyeyemi O. A. and Olanlokun J. O. (2009). Chemical compositions, Phytochemical constituents and in vitro biological activity of various extracts of cymbopogon citratus. Pakistan Journal of Nutrition, 8 (12),1920-1922.

[17] Ejoh A. R., Tanya A. N., Djuikwo A. N. and Mbofung C. M. (2005). Effect of processing and preservation methods on vitamin $\mathrm{C}$ and total carotenoids levels of some Vernonia (Bitter) species. African Journal of Food, Agriculture, Nutrition and Development, 5(2),1-7.

[18] Oboh G. (2005). Effect of blanching on the antioxidant property of some tropical green leafy vegetables. Food Science Technonology LWT, 38,513-517.

[19] Omotade I. O. (2009). Chemical profile and antimicrobial activity of Cymbopogon citratus leaves. Journal of Natural Products, 2,98-103.

[20] Magdi A. O. (2004). Chemical and nutrient analysis of baobab (Adansonia digitata) fruit and seed protein solubility. Plant Foods for Human Nutrition, 59,29-33.

[21] Igile G. O., Oleszek W., Burda S. and Jurzysta M. (1995). Nutritional assessment of Vernonia amygdalina leaves in growing mice. Journal of Agricultural and Food chemistry, 43(8),2162-2166.

[22] Han X., Shen T. and Lou H. (2007). Dietary polyphenols and their biological significance. International Journal of Molecular Science, 8,950-988. 
[23] Adewole E., Ojo A., Ogunmodede O. T. and Adewumi D. F. (2015). Antioxidant activities and nutritional compositions of Vernonia amygdalina. International Journal of Basic and Applied Science, $4(1), 9-16$.

[24] Soetan K. O., Oyekunle M. A., Aiyelaagbe O. O., Fafunso M. A. (2006). Evaluation of the antimicrobial activity of saponins extract of Sorghum bicolor L. Moench. African Journal of Biotechnology, 5(23),2405-2407.

[25] Osagie A. U. (1998). Antinutritional Factors in Nutritional Quality of Plant Foods. Ambik Press Ltd Benin City, Nigeria, 40p.

[26] Agte, V. V., Tarwadi, K. V. and Chiplonkar, S. A. (1999). Phytate degradation during traditional cooking: Significance of the phytic acid profile in cereal-based vegetation meals. Journal of Food Composition and Analysis, 12,161-167.

[27] Ladeji, O., Akin, C. U. and Umaru, H. A. (2004). Level of antinutritional factors in vegetables commonly eaten in Nigeria. African Journal of Natural Science,71-73.

[28] Oguchi Y., Weerakkody W. A. P., Tanaka A., Nakazawa S. and Ando T. (1996). Varietal differences of quality-related compounds in leaves and petioles of spinach grown at two locations. Bulletin of the Horishima Prefectural Agriculture Research Center, 64,1-9.

[29] Anhwange, B.A., Ugye, T. J. and Nyiaatagher, T. D. (2009). Chemical composition of Musa sapientum (banana) peels. Electronical Journal of Environmental, Agricultural and food chemistry, 8 (6), 437-442. 